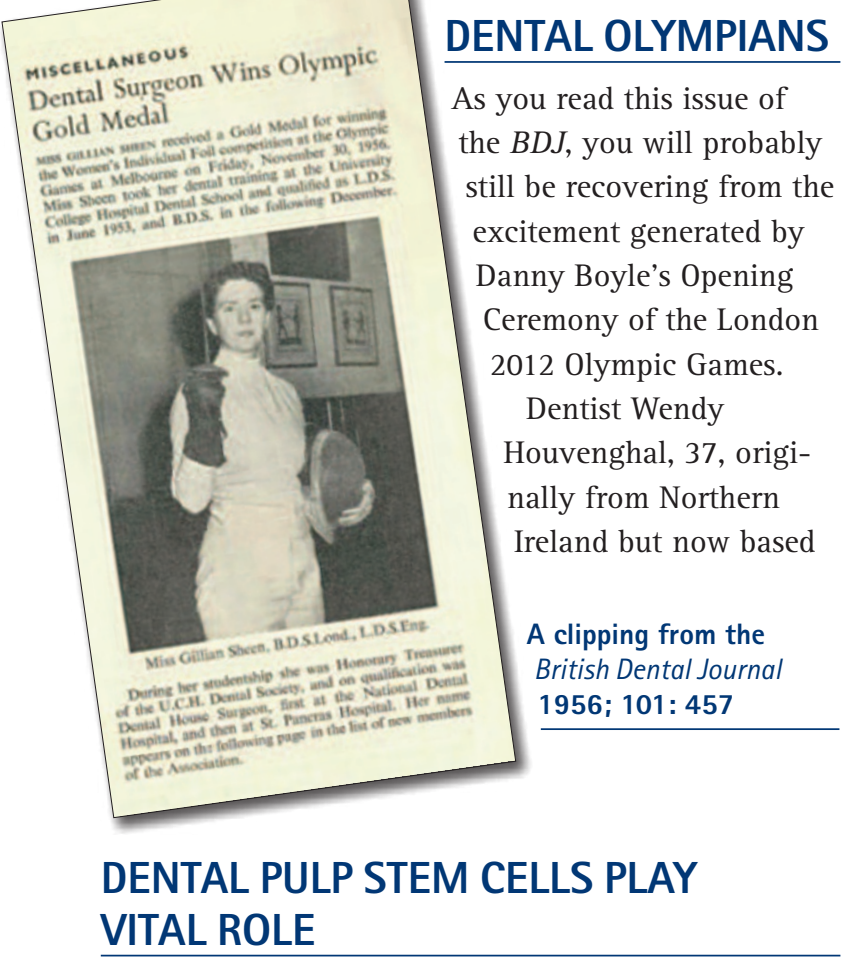

Mesoblast, a leading global stem cell therapy development company, has taken out exclusive rights to patents covering dental pulp stem cells (DPSC), with the hope of treating conditions such as Parkinson's disease and stroke.

In their presentation to the Jeffries Annual Global Healthcare Conference in June, ${ }^{1}$ Mesoblast suggested DPSC will play a vital role in their new corporate strategy for product development to treat neurologic conditions. Recent studies have shown that due to their neural crest origin, DPSC have unique properties, which make them more effective in the protection and repair of neural cells and tissues than other adult stem cells. Research by Karaöz et al. ${ }^{2}$ emphasises the special characteristics of DPSC, with an in vitro study demonstrating how the pulp stem cells were able to differentiate into neural cells as well as vascular epithelial cells. The conclusions of the study are promising for the development of clinical uses of DPSC for neurodegenerative diseases.

DPSC are STR0-1 (a stem cell marker) positive, making them highly suitable for regenerative treatments. As producers of high levels of neurotrophic factors, Mesoblast is focusing on using their potential in the treatment of Huntington's and Parkinson's, affecting almost 135,000 in the UK; stroke, affecting around 150,000 each year in the UK; and acute spinal cord injury, paralysing approximately 1,200 each year in the UK.

1. Mesoblast. Presentation to the Jeffries Annual Global Healthcare Conference. 2012. Online presentation available at www.mesoblast. com/investors/presentations/ (accessed June 2012).

2. Karaöz E, Demircan P C, Sağlam O, Aksoy A, Kaymaz F, Duruksu G. Human dental pulp stem cells demonstrate better neural and epithelial stem cell properties than bone marrow-derived mesenchymal stem cells. Histochem Cell Biol 2011; 136: 455-473.

By Laura Pacey in Cornwall, has put her dental career temporarily on hold as she prepares to compete at this year's Olympics in the track cycling team pursuit. Dr Houvenghal has been a full-time athlete for six years, won a silver medal in the individual pursuit in track cycling at the Beijing Olympic Games in 2008 and gold in the team pursuit at the 2008, 2009 and 2011 Track World Championships.

Another notable dental Olympian was fencer Gillian Sheen, who received a gold medal for winning the Women's
Individual Foil competition at the Melbourne Olympic Games in 1956 at the age of 28 (she became a member of the BDA the same year). Gillian, who went to school in Kent then studied dentistry at University College Hospital, London, was the surprise winner of the gold medal. She went on to win the British Empire and Commonwealth title in 1958 and in 1960 won her tenth and final British Championship. Gillian, whose married name is Donaldson, later settled in New York where she joined her husband in a dental practice.

\title{
ARMY DENTAL DUO TRAIN WITH TEAM GB
}

Members of the British Dental Association (BDA) Armed Forces travelled to Monte Gordo, Portugal in May with the Army Medical Services (AMS) Athletics Team to complete a training camp before the outdoor military athletics season got underway.

Major Tom Konarzewski (pictured left - Defence Dental Services, Chester) and Captain Rich Smith (right - Army Foundation College, Harrogate) are serving officers in the Royal Army Dental Corps.

The dental duo were representing the AMS alongside combat medics, doctors and medical staff of the British Army at the Real De San Antonio Sports Complex and found themselves training alongside some of this summer's Team
GB 2012 medal hopes. Athletes included long jumper and threetime Olympian Chris Tomlinson, heptathlete Louise Hazel, sprint sensation Adam Gemili and world triple jump medallist Philips Idowu.

Inspired by their encounters and the revelation that Philips was an avid $B D J$ reader, the Army pair returned to the UK where Major Konarzewski won a bronze medal in the javelin at the Army Champs and Capt Smith went on to win his fifth Inter-Services $400 \mathrm{~m}$ hurdle title competing against the RAF and Navy. Capt Smith has also been selected to be a part of the London 2012 Medical Team in his spare time, providing dental cover at various venues in the Olympic Village.

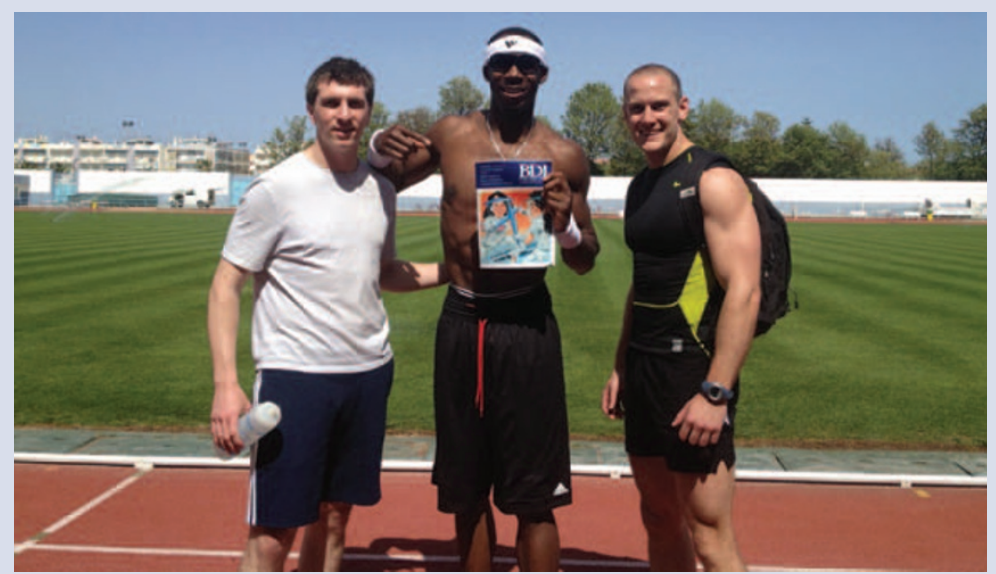

Olympic gold medal hope Philips Idowu (centre) catching up on his verifiable CPD 